\title{
Inducible clindamycin resistance and erm genes in Staphylococcus aureus in school children in Kathmandu, Nepal
}

\author{
Roshan Timsina ${ }^{1}$, Upasana Shrestha (iD) Anjana Singh ${ }^{1}$ \& Bivek Timalsina*,2 (i) \\ ${ }^{1}$ Central Department of Microbiology, Tribhuvan University, Kathmandu, Nepal \\ ${ }^{2}$ Center for Health \& Disease Studies-Nepal (CHDS), Shankhamul, Kathmandu, Nepal \\ *Author for correspondence: Tel.: +977 984174 4582; btimalsina@chdsnepal.org
}

\begin{abstract}
Aim: Resistance to methicillin and Macrolide-Lincosamide and Streptogramins B and their association with erm genes in Staphylococcus aureus are unknown in Nepal. Materials \& methods: Nonduplicate nasal swabs from 160 school children were collected from April to September 2018 and processed using standard microbiological procedures. Results: Out of 160 samples, 64 (40\%) were S. aureus in which $17(26.6 \%)$ were methicillin-resistance Staphylococcus aureus (MRSA). D-test identified $15(23.4 \%)$ as inducible clindamycinresistant, which were more prevalent in MRSA (76.4\%) than methicillin-sensitive S. aureus (MSSA; $4.2 \%)$. $18.7 \%$ of isolates harbored the ermC gene followed by ermA (15.6\%) and ermB (3.1\%), and were more in MRSA than MSSA. Conclusion: To prevent treatment failure by inducible resistance, D-test must be performed on erythromycin-resistant and/or clindamycin-sensitive isolates.
\end{abstract}

Lay abstract: With the increased prevalence of methicillin-resistant $S$. aureus in hospital- and community-acquired infections, there has been an upsurge in resistance toward Macrolide-LincosamideStreptogramin type B antibiotics. This has rendered therapy difficult, thereby increasing morbidity, length of hospital-stay and cost of treatment. Therefore, the correct identification and reporting of S. aureus isolates and their susceptibility patterns, more specifically, toward methicillin, clindamycin and erythromycin is very crucial.

First draft submitted: 24 May 2020; Accepted for publication: 13 August 2020; Published online: 20 October 2020

Keywords: antibiotic resistance $\bullet$ D-test $\bullet$ erm $\bullet$ erythromycin $\bullet$ inducible clindamycin resistance $\bullet$ methicillinresistant Staphylococcus aureus $\bullet$ Nepal

Staphylococcus aureus, especially methicillin-resistant $S$. aureus (MRSA) was frequently isolated and identified to be the cause of nosocomial and community-acquired infections [1]. Previously, S. aureus was sensitive to glycopeptides such as vancomycin and teicoplanin but during recent years these organisms have developed resistance to these antibiotics, which has encouraged physicians to prescribe another family of antibiotics as an alternative; macrolidelincosamide-streptogramin type B $\left(\mathrm{MLS}_{\mathrm{B}}\right)[2,3]$.

Both MRSA and methicillin-sensitive S. aureus (MSSA) can be treated by clindamycin, an $\mathrm{MLS}_{\mathrm{B}}$ antibiotic which is of low cost, and has fewer side effects and high bioavailability in both oral and parenteral forms [4]. Although they are chemically different, the $\mathrm{MLS}_{\mathrm{B}}$ group exhibits similar inhibitory effects in bacterial protein synthesis [3,5]. There are several mechanisms to $\mathrm{MLS}_{\mathrm{B}}$ resistance, which include macrolide efflux pump, target site modification and enzymatic antibiotic inactivation [3,6]. Among them target site modification is predominant, which is mediated by the erm gene [3,5]. Four genes, namely erm $A$, ermB, erm $C$ and $\operatorname{erm} F$, are frequently associated with resistance to $\mathrm{MLS}_{\mathrm{B}}$ [7-10]. These genes produce methylase, an enzyme that modifies the ribosomal target site preventing binding of the antibiotic and leading to constitutive and inducible resistance [8,11]. Inducible resistance is developed when a strong inducer of the methylase enzyme, erythromycin, is present. Such an isolate is susceptible to clindamycin but resistant to erythromycin. D-zone effect or erythromycin induction of clindamycin resistance using the disk-diffusion method provides proof of this statement [12]. Therefore, it is very crucial to identify actual 
$M L S_{B}$ resistance for prescribing appropriate therapy in infected patients [13]. If the patient is prescribed with clindamycin without the proper identification of $\mathrm{MLS}_{\mathrm{B}}$ resistance, it can lead to treatment failure [14].

We found multiple studies reporting variable rates of inducible clindamycin resistance in different places [2,15-22]. Moreover, prevalence rates of different erm genes are still understudied in Nepal. Therefore, the aim of this study is to give an exact picture of what the prevalence of these genes are in the Nepal community. This will provide a proper direction for future researchers as well as prevent health professional from prescribing antibiotics relating to this condition.

\section{Materials \& methods Materials}

All the microbiological media and antibiotic discs were purchased from HiMedia Pvt. Ltd., Co., Mumbai, India. Other chemicals were purchased as primer (integrated DNA technology), Master mix (Takara Bio Inc., Nojihigashi, Japan), DNA Ladder (GeneDirex, Inc., MD, USA), Good view nucleic acid stain- HGV II (SBS Genetech Co., Ltd, Beijing, China), agarose (GeneDireX, Inc.).

\section{Sample collection}

After the approval from Nepal Health Research Council, National Ethical Guidelines for Health Research in Nepal (reg. no. 195/2O18), a prospective cross-sectional study was conducted over 6 months of period to isolate $S$. aureus from nasal samples collected from students of two different schools of Kathmandu, namely Kirtipur Secondary and Mangal Secondary School. The informed consent was taken from guardian of students before sample collection. Only those participants (school children) who were not taking any medications were included in the study. Nasal swabs were collected by inserting a sterile moistened cotton swabs (HiMedia) into each nostril and transferred to the laboratory keeping in transport media. The laboratory tests were conducted from April-September 2018 in the Microbiology lab of Center for Health and Disease Studies, Nepal. A total of nonduplicate 160 samples were analyzed in the study.

\section{Bacterial isolation \& identification}

The specimens collected were inoculated in mannitol salt agar (MSA), blood agar (BA) and incubated at $37^{\circ} \mathrm{C}$ aerobically for $24 \mathrm{~h}$. Beta hemolytic colonies on blood agar and typical mannitol fermenting colonies in MSA were observed. Pin-point-sized colonies on blood agar with diameter of 2-3 $\mathrm{mm}$ were indicative of $S$. aureus. Gram stain, catalase, oxidase, $\mathrm{O}-\mathrm{F}$ and coagulase (free and bound) test were performed for further identification using a standard microbiological techniques [23].

\section{Antibiotic susceptibility testing}

Antimicrobial susceptibility was studied by the Kirby-Bauer disk diffusion method on a Mueller-Hinton agar plate (12-cm diameter), following Clinical Laboratory Standard Institute (CLSI) guidelines [1,19]. The tested antimicrobial agents were: penicillin $(10 \mathrm{U})$, cefoxitin $(30 \mu \mathrm{g})$, gentamicin $(10 \mu \mathrm{g})$, erythromycin $(15 \mu \mathrm{g})$, clindamycin $(2 \mu \mathrm{g})$ and ciprofloxacin $(5 \mu \mathrm{g})$. Cefoxitin $(30 \mu \mathrm{g})$ was used for the detection of methicillin resistance. Erythromycin $(15 \mu \mathrm{g})$ and clindamycin $(2 \mu \mathrm{g})$ discs placed $15 \mathrm{~mm}$ apart were used for detection of inducible clindamycin resistance as per recommended CLSI guidelines [23,24].

\section{Detection of methicillin resistance}

With cefoxitin disks, isolates with zone of inhibition $\geq 22 \mathrm{~mm}$ in diameter were considered methicillin resistance and those with $\leq 21 \mathrm{~mm}$ were considered as methicillin susceptible.

\section{Detection of inducible clindamycin resistance}

Formation of a flattening shape of the clindamycin inhibition zone $\geq 21 \mathrm{~mm}$ (D shape) around the erythromycin disk has shown in Figure 1, which indicates that erythromycin has induced clindamycin resistance.

ATCC 25923 strains of $S$. aureus were used to perform quality control. A separate in-house strain that showed inducible clindamycin resistance was also used for quality control.

\section{DNA extraction}

Genomic DNA was extracted from S. aureus isolates from QIAamp DNA Mini Kit, Cat No./ID: 51304 (Qiagen). One to two colonies of isolates were taken with nichrome loop, suspended in nutrient broth and incubated for 24 


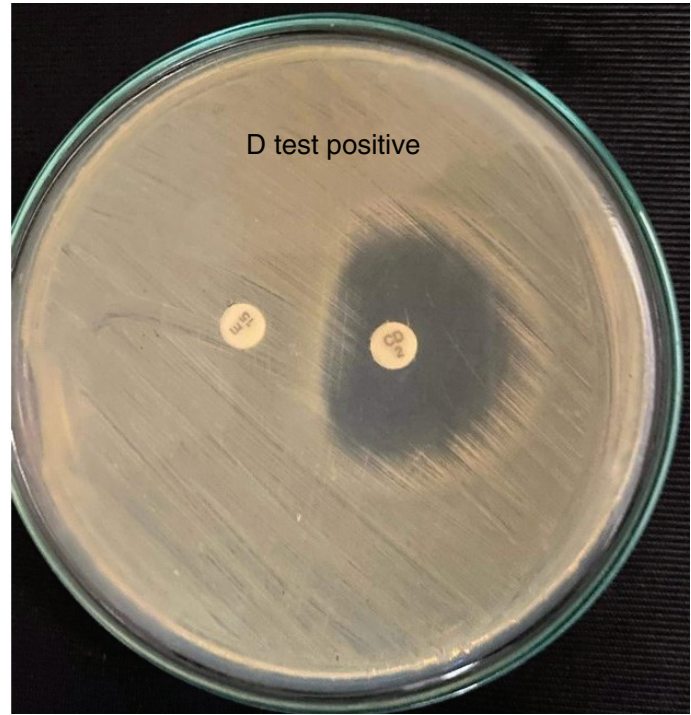

Figure 1. Inducible clindamycin resistant (D-test) positive showing MRSA in MHA media.

CD: Clindamycin; E: Erythromycin; MHA: Muller hinton agar; MRSA: Methicillin-resistant Staphylococcus aureus.

h. The turbidity was checked and DNA was extracted according to the manufacturer's protocol of QIAamp. The extracted DNA was kept in $-20^{\circ} \mathrm{C}$ until used for PCR.

\section{Amplification of ermA, ermB \& ermC genes}

DNA amplification was performed using specific primers for detection of erm genes. Primer sequences were designed using Primer-BLAST of NCBI using gene ID 13913675 for ermA and 24247827 for ermC. Primer sequence for $\operatorname{ermB}$ was used from research paper [8]. Sequences for primers used for PCR were as follows: ermA/F: 5'-AAGCGGTAAACCCCTCTGA-3, ermA/R: 5'-TTCGCAAATCCCTTCTCAAC-3 with amplicon size of $190 \mathrm{bp}, \mathrm{ermB} / F$ : 5'-CATTTAACGACGAAACTGGC-3', ermB/R: 5'-GGAACATCTGTGGTATGGCG-

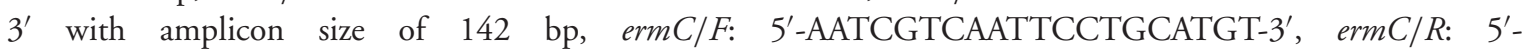
TAATCGTGGAATACGGGTTTG-3' with amplicon size of 299 bp. Each reaction was carried out in final volume of $25 \mu \mathrm{l}$ with Mastermix $(12 \mu \mathrm{l})$, forward primer $(1 \mu \mathrm{l})$, reverse primer $(1 \mu \mathrm{l})$, DNA template $(4 \mu \mathrm{l})$ and $7 \mu \mathrm{l}$ nuclease-free water. PCR amplifications were adjusted according to conditions described in previous studies with some modification [12]. Amplification conditions were as follows: initial denaturation $\left(94^{\circ} \mathrm{C} / 4 \mathrm{~min}\right.$ for $\mathrm{ermA}$, $95^{\circ} \mathrm{C} / 2 \mathrm{~min}$ for $\mathrm{ermB}, 95^{\circ} \mathrm{C} / 2 \mathrm{~min}$ for $\mathrm{ermC}$ ), denaturation $\left(94^{\circ} \mathrm{C} / 30 \mathrm{~s}\right.$ for $\mathrm{ermA}, 95^{\circ} \mathrm{C} / 30 \mathrm{~s}$ for $\mathrm{ermB}, 95^{\circ} \mathrm{C} / 30 \mathrm{~s}$ for $\operatorname{erm} C)$, various annealing temperatures $\left(55^{\circ} \mathrm{C} / 30 \mathrm{~s}\right.$ for $\mathrm{ermA}, 50.2^{\circ} \mathrm{C} / 30 \mathrm{~s}$ for ermB, $52.4^{\circ} \mathrm{C} / 30 \mathrm{~s}$ for erm C) and $72^{\circ} \mathrm{C} / 30 \mathrm{~s}$ and final extension at $72^{\circ} / 5 \mathrm{~min}$ and hold at $4^{\circ} \mathrm{C}$ for infinity. PCR products were analyzed by separating on $1.8 \%$ agarose gel electrophoresis, stained with nucleic acid stain solution and finally visualized in gel documentation system [12]. A reaction containing all materials and nuclease-free water except template DNA was used as negative control. A native isolate harboring $\operatorname{erm} A, \operatorname{ermB}$ and $\operatorname{erm} C$ gene was used as a positive control for erm genes. 100 bp ladder from GeneDireX, Inc. was used to identify the size of amplified products.

\section{Statistical analyses}

Microsoft Excel 2016 was used to keep the record of the data. The data were analyzed using SPSS version 25 for Windows. Pearson Chi-square test was used to find the association between the two variables. p-value of less than 0.05 was considered statistically significant.

\section{Results}

Isolation of S. aureus \& antibiotic susceptibility pattern

In this study, out of 160 samples processed, 64 samples showed positive culture growth for $S$. aureus in which 17 (26.5\%) were MRSA. The antimicrobial sensitivity tests among MRSA showed that all isolates were resistance to penicillin (ten units) and highly sensitive (88.2\%) to gentamicin. The results of antibiotic susceptibility testing for other antibiotics are shown in Table 1. 
Table 1. Result of antibiogram test for methicillin-resistance Staphylococcus aureus isolates.

\begin{tabular}{llll} 
Antibiotics used & Sensitive (\%) & Intermediate (\%) & Resistant (\%) \\
\hline Gentamycin $(10 \mu \mathrm{g})$ & $16(88.2)$ & - & $1(5.8)$ \\
\hline Erythromycin $(15 \mu \mathrm{g})$ & $4(23.5)$ & $3(17.6)$ & $10(58.8)$ \\
\hline Clindamycin $(2 \mu \mathrm{g})$ & $12(70.5)$ & $2(11.7)$ & $3(17.6)$ \\
\hline Penicillin (ten units) & 0 & 0 & $17(100)$ \\
\hline Ciprofloxacin $(5 \mu \mathrm{g})$ & $6(35.2)$ & $1(5.8)$ & $10(58.8)$ \\
\hline
\end{tabular}

\section{Table 2. Distribution of inducible macrolide-lincosamide-streptogramin type B among methicillin-resistance}

Staphylococcus aureus, methicillin-sensitive $S$. aureus and total isolates.

\begin{tabular}{|c|c|c|c|}
\hline Property & MRSA $(n=17)$ & MSSA $(n=47)$ & Total isolates $(n=64)$ \\
\hline Inducible clindamycin resistance (iMLS $_{B}$ ) & $13(76.4 \%)$ & $2(4.2 \%)$ & $15(23.4 \%)$ \\
\hline
\end{tabular}

\begin{tabular}{|c|c|c|c|}
\hline \multirow[t]{2}{*}{ Genotype } & \multirow[t]{2}{*}{ PCR result } & \multicolumn{2}{|c|}{ Sensitivity to methicillin } \\
\hline & & MRSA (\%) & MSSA (\%) \\
\hline \multirow[t]{2}{*}{ ermA } & Positive & 58.8 & 4.2 \\
\hline & Negative & 41.2 & 95.8 \\
\hline \multirow[t]{2}{*}{ ermB [30] } & Positive & 11.7 & 0 \\
\hline & Negative & 88.3 & 0 \\
\hline \multirow[t]{2}{*}{ ermc } & Positive & 70.5 & 0 \\
\hline & Negative & 29.5 & 0 \\
\hline
\end{tabular}

Inducible clindamycin resistance

Inducible clindamycin resistance was seen among $15(23.4 \%)$ of the total isolates. The distribution of iMLS $_{\mathrm{B}}$ among MRSA, MSSA and total isolates showed the higher rate of inducible clindamycin resistance in MRSA compared with MSSA $(\mathrm{p} \leq 0.05)$ as shown in Table 2 .

\section{Association of erm genes in MRSA \& MSSA}

As shown in Table 3 and Figures 2-4, the electrophoresis results of PCR amplicon showed that $15.6 \%$ were ermA positive, $3.1 \%$ were $\mathrm{ermB}$ positive and $18.7 \%$ were $\mathrm{erm} C$ positive in which three isolates had both ermA and erm $C$ genes. In this study, the MRSA isolates harbored the erm genes in which ermB and $\operatorname{erm} C$ genes were only present in MRSA, whereas few MSSA also had ermA genes.

\section{Discussion}

S. aureus infection is one of the major causes of infection, mainly in low- and middle-income countries and the rate of emergence of antibiotic resistance is quite alarming [25].

We found a significant number of $S$. aureus from school children, which also show resistance to methicillin, erythromycin and clindamycin. It is very important to correctly identify and report $S$. aureus isolates, especially in clinical and diagnostic settings, including whether the isolates are truly susceptible to clindamycin when they are resistant to erythromycin. A simple D-test can be performed in the laboratory, so that inducible clindamycin-resistant isolates can be excluded for clindamycin therapy [26]. Prevalence of $S$. aureus in a community is multifactorial in nature, depending on the geographical location, socioeconomic status, patient age, species of bacteria, inconsistent use of erythromycin and source of the strain (community or nosocomial) $[7,27]$.

The results of our study have shown that the prevalence of inducible clindamycin resistance was $23.4 \%$ among all the isolates. As shown in Table 4, several studies conducted in different parts of the world are inconsistent with the prevalence of $i M L S_{B}$ and have previously reported higher variability in prevalence, which ranged from 3.3 to $43 \%[4,11,13,15,16,21,25,28-33]$. Also, the prevalence of iMLS $_{B}$ resistance in MRSA was $76.4 \%$, which is much higher than the prevalence rate previously reported by different studies, which were $12.3-35.9 \%[4,10,25,29,30,34,35]$. This 


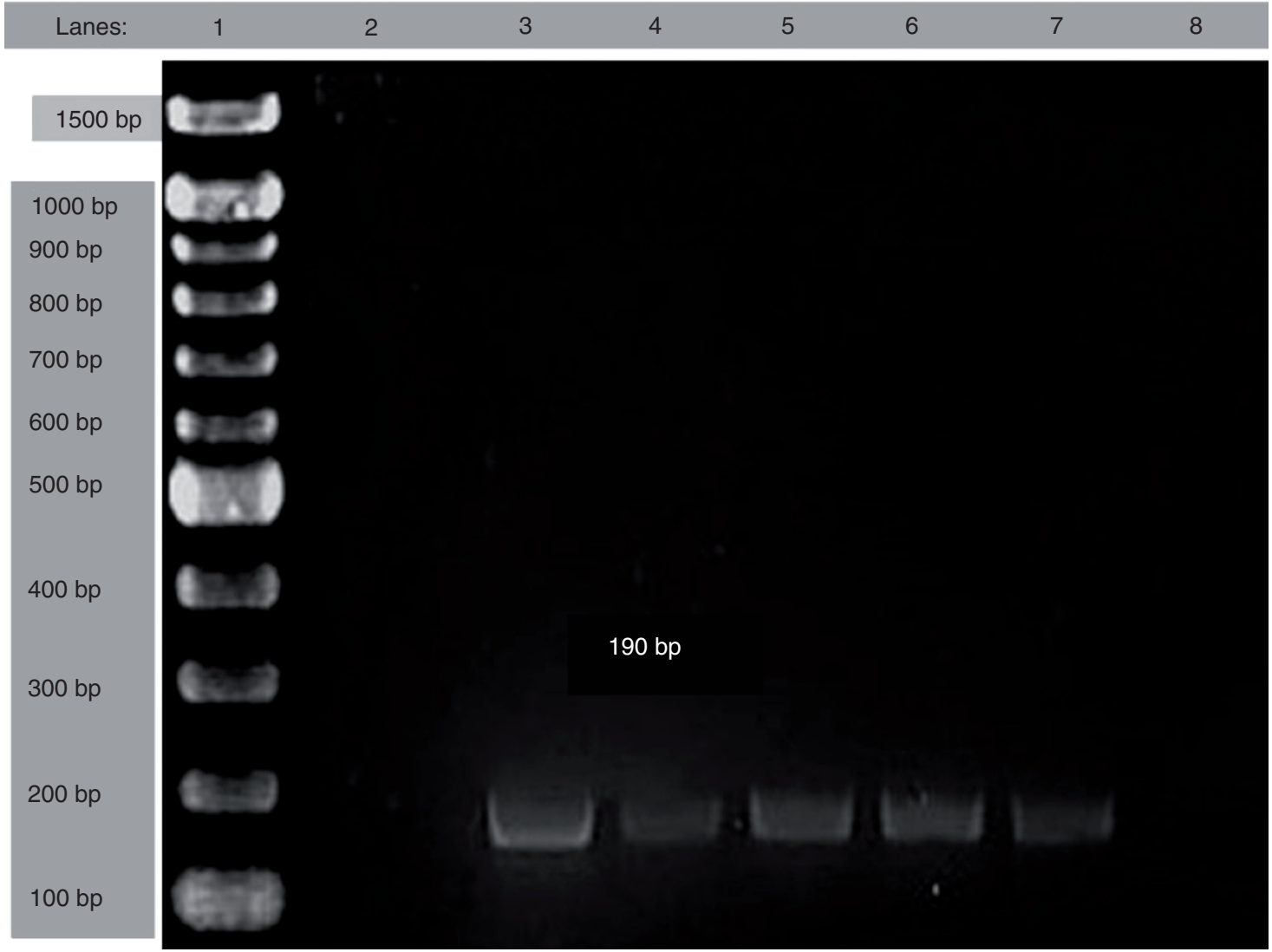

Figure 2. Electrophoresis result of ermA gene. Lane 1:DNA marker, Lane 2: negative control; Lane 3: positive control; Lane 4-8: samples and 190 bp for ermA.

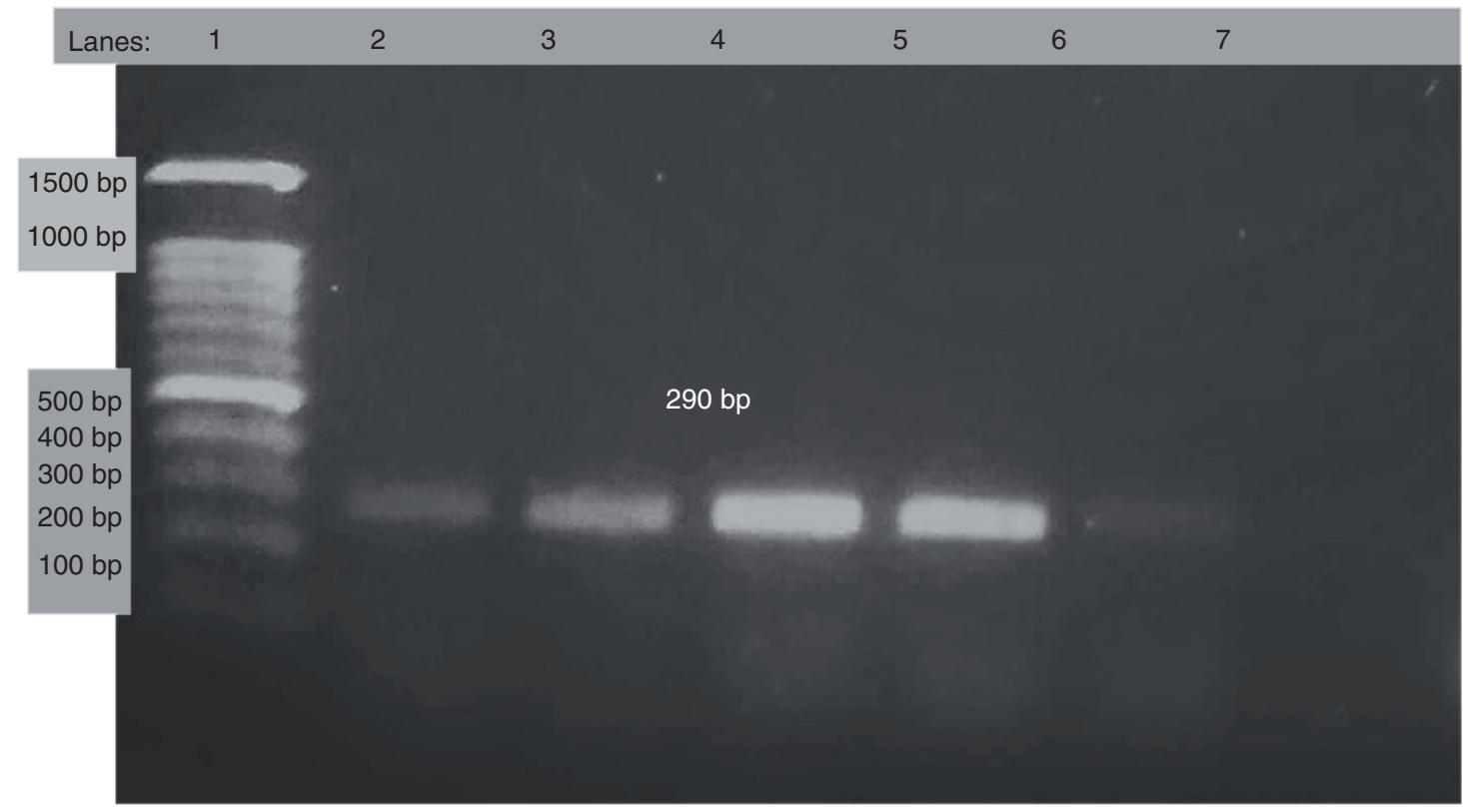

Figure 3. Electrophoresis result of ermC gene. Lane 1: DNA marker, Lane 2: positive control; Lane 3-7:samples and $299 \mathrm{bp}$ for ermC. 


\section{S. aureus isolates}

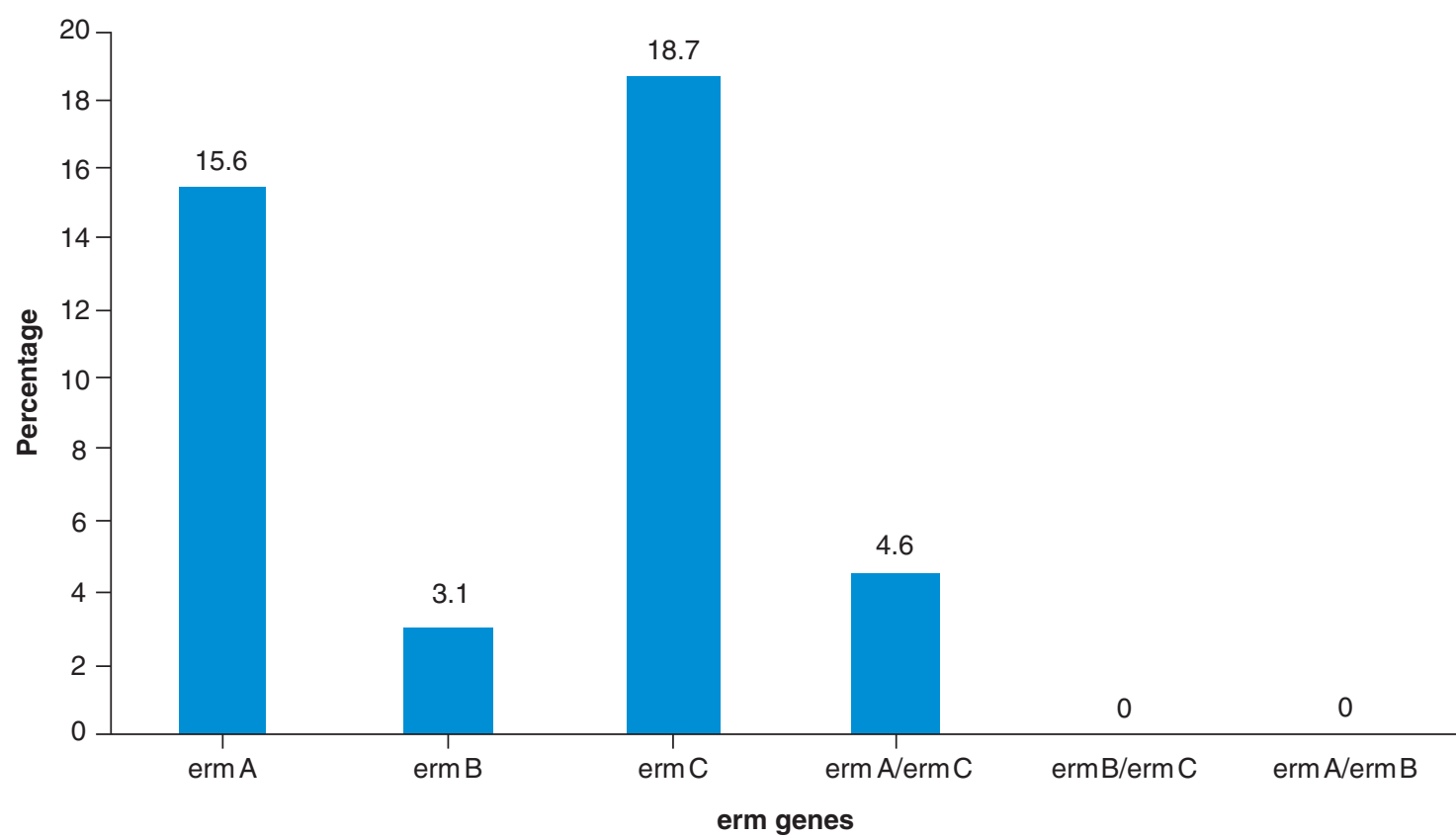

Figure 4. Frequency of erm genes in S. aureus isolates.

\begin{tabular}{|c|c|c|c|c|c|}
\hline \multirow[t]{2}{*}{ Study (year) } & \multicolumn{3}{|c|}{ Inducible resistance isolates } & \multirow{2}{*}{$i M L S_{\mathrm{B}}(\%)$} & \multirow[t]{2}{*}{ Ref. } \\
\hline & ermA (\%) & ermB $(\%)$ & ermC (\%) & & \\
\hline Lina et al. (1999) & 63.2 & 0.7 & 25 & 30.2 & [24] \\
\hline Hamilton-Miller et al. (2000) & - & - & - & 43 & [31] \\
\hline Fiebelkorn et al. (2003) & - & - & - & 25.2 & [25] \\
\hline Vivian et al. (2010) & 29.6 & 17.1 & 0.66 & 3.3 & [23] \\
\hline Moosavian et al. (2014) & 41.1 & Nonprevalent & 17.7 & 32.3 & [12] \\
\hline Aydeniz et al. (2015) & 81.9 & 0.9 & 10.8 & 27.47 & [26] \\
\hline Havaei et al. (2016) & 11.11 & 22.22 & 44.44 & 4.18 & [22] \\
\hline Fasihi et al. (2016) & 11 & 3.5 & 20.5 & 12.5 & [11] \\
\hline Adhikari et al. (2017) & - & - & - & 11.48 & [17] \\
\hline Khashei et al. (2018) & - & - & - & 8.6 & [9] \\
\hline Our study & 66.67 & 13.33 & 73.38 & 23.4 & [30] \\
\hline
\end{tabular}

indicates an alarming increase in antibiotic resistance. Although MLS $_{\mathrm{B}}$ resistance in MRSA was higher, it was within the range (4-68\%) when compared with data of previously reported studies among MSSA [4,10,25,34,35].

Results from our PCR study showed that the prevalence of ermA, ermB and $\operatorname{erm} C$ genes were: 15.62, 3.12 and $18.75 \%$, respectively, among inducible clindamycin-resistant isolates. Prevalence of erm $A$ gene varied among different studies conducted at different geographic location, which ranged from 11 to $81.9 \%$ [11,15,16,28,29,31]. Our study was within this range obtained from those previously conducted. Our study also showed the prevalence of $\mathrm{erm} C$ gene to be within the range when compared with the rates previously reported by several studies [11,15,16,28,31], which ranged from 0.66 to $44.44 \%$. Due to lack of the pertinent literature in different erm genes in Nepal, our study aimed to determine the prevalence of ermA, ermB and $\operatorname{erm} C$ genes from $S$. aureus isolates and inducible clindamycin-resistant MRSA isolates. The prevalence of $\operatorname{erm} A$, $\operatorname{erm} B$ [36] and $\operatorname{erm} C$ genes among iMLS $S_{\mathrm{B}}$ isolates were $66.67,13.33$ and $73.38 \%$, respectively. The comparison of the prevalence rates of erm $A$, erm $B$ and $\operatorname{erm} C$ genes in different studies are given in Table 2. 


\section{Limitations}

Regarding the limitations of our study, it was conducted in two different schools of Kirtipur, Kathmandu, Nepal and so while there may be a chance of us extrapolating our findings and applying it across Kathmandu valley, this may not be representative of the whole country. However, Kathmandu is the most populated city in Nepal. Hence, our findings could well represent the whole country. Due to lack of resources and funding, we were not able to perform genotyping or Staphylococcal cassette chromosome mec gene (SSCmec) typing of S. aureus. Furthermore, MIC of antibiotics used was not determined.

\section{Conclusion \& recommendations}

To conclude, this study identified the significant presence of MRSA in nasal swabs from school children, which clearly emphasizes the importance of sanitation. Furthermore, there is an increase in inducible clindamycin resistance that directly impacts the treatment of the cases. Therefore, this highlights the importance of performing D-test to identify these isolates in detail, which ought to be followed by laboratory in routine identification of $S$. aureus.

\section{Future perspective}

As there is presence of significant numbers of $S$. aureus in Nepalese school children as well as resistance to several antibiotics, more research should be done in this area to identify the pathogens, their virulence factors and antibioticresistance patterns in order to mitigate the misuse of antibiotics. Furthermore, characterization of gene sequences and typing of strain will give more insight into the genes involved in resistance development.

\section{Summary points}

- Methicillin-resistance Staphylococcus aureus and inducible clindamycin resistance are emerging as a public health threat, which could lead to increased morbidity and mortality if proper diagnosis and treatment are not done.

- There is a significant association of ermA, ermB, ermC genes and inducible clindamycin resistance, which can be used for rapid diagnosis and treatment.

- Inducible clindamycin resistance was found to be more among methicillin-resistance S. aureus.

- Every diagnostic and microbiology laboratories should perform D-test to identify inducible clindamycin resistance if they encounter $S$. aureus isolates sensitive to clindamycin but resistant to erythromycin.

\section{Author contributions}

R Timsina, B Timalsina and A Singh conceived and designed the study. B Timalsina designed the primers and PCR assay. R Timsina and $U$ Shrestha processed the samples and performed microbiological tests. R Timsina, U Shrestha and B Timalsina performed molecular biology tests. B Timalsina and A Singh supervised the work and manuscript. All the authors made substantial contributions to editing and writing the manuscript. All the authors read and approved the final manuscript.

\section{Acknowledgments}

The authors sincere thank to Narayan Sharma Bashyal of Central Department of Microbiology and Samikshya Kafle of Center for Health and Disease Studies-Nepal (CHDS) for laboratory support. They are thankful to CHDS and Central Department of Microbiology for providing them the lab facilities.

\section{Financial \& competing interests disclosure}

The authors have no relevant affiliations or financial involvement with any organization or entity with a financial interest in or financial conflict with the subject matter or materials discussed in the manuscript. This includes employment, consultancies, honoraria, stock ownership or options, expert testimony, grants or patents received or pending, or royalties.

No writing assistance was utilized in the production of this manuscript.

Ethical conduct of research

A written informed consent from parents/guardians of all participants (all aged below sixteen years) was taken prior to the study. The ethical permission was sought from the Ethical Board of Nepal Health Research Council (NHRC), Ram Shah Path, Kathmandu, Nepal (reg no. 195/2018). 
Open access

This work is licensed under the Creative Commons Attribution 4.0 License. To view a copy of this license, visit http://creativecomm ons.org/licenses/by/4.0/

\section{References}

Papers of special note have been highlighted as: $\bullet$ of interest; $\bullet \bullet$ of considerable interest

1 Lima De Castro Nunes E, Dos Santos KRN, Mondino PJJ, De Freire Bastos MDC, Giambiagi-Demarval M. Detection of ileS-2 gene encoding mupirocin resistance in methicillin-resistant Staphylococcus aureus by multiplex PCR. Diagn. Microbiol. Infect. Dis. 34(2), 77-81 (1999).

2 Joshi PR, Acharya M, Kakshapati T, Leungtongkam U, Thummeepak R, Sitthisak S. Co-existence of bla OXA-23 and bla NDM-1 genes of Acinetobacter baumannii isolated from Nepal: antimicrobial resistance and clinical significance. Antimicrob. Resist. Infect. Control. 6(1), 1-7 (2017).

- Provides information on resistance to Macrolide-Lincosamide-Streptogramin type B $\left(\mathrm{MLS}_{\mathrm{B}}\right)$.

3 Leclercq R. Mechanisms of resistance to macrolides and lincosamides: nature of the resistance elements and their clinical implications. Clin. Infect. Dis. 34(4), 482-492 (2002).

4 Baral R, Khanal B. Inducible clindamycin resistance in Staphylococcus aureus strains isolated from clinical samples. Int. J. Biomed. Res. 8(2), 81-84 (2017).

5 Roberts MC, Sutcliffe J, Courvalin P, Jensen LB, Rood J, Seppala H. Nomenclature for macrolide and macrolide-lincosamide-streptogramin B resistance determinants. Antimicrob. Agents Chemother. 43(12), 2823-2830 (1999).

6 Kasten MJ. Clindamycin, metronidazole, and chloramphenicol. In: Mayo Clinic Proceedings. Elsevier Ltd, Mayo Clinic Rochester, MN, USA, 825-833 (1999).

7 Aktas Z, Aridogan A, Kayacan CB, Aydin D. Resistance to macrolide, lincosamide and streptogramin antibiotics in Staphylococci isolated in Istanbul, Turkey. J. Microbiol. 45(4), 286-290 (2007).

- Explains the association of ermA, ermB, ermC and ermF genes for resistance to $\mathrm{MLS}_{\mathrm{B}}$.

8 Jensen LB, Frimodt-Møller N, Aarestrup FM. Presence of erm gene classes in Gram-positive bacteria of animal and human origin in Denmark. FEMS Microbiol. Lett. 170(1), 151-158 (1999).

9 Saderi H, Emadi B, Owlia P. Phenotypic and genotypic study of macrolide, lincosamide and streptogramin B (MLS $\left.S_{B}\right)$ resistance in clinical isolates of Staphylococcus aureus in Tehran, Iran. Med. Sci. Monit. 17(2), BR48-BR53 (2011). www.pubmedcentral.nih.gov/articlerender.fcgi?artid=3524716\&tool=pmcentrez\&rendertype=abstract

10 Levin TP, Suh B, Axelrod P, Truant AL, Fekete T. Potential clindamycin resistance in clindamycin-susceptible, erythromycin-resistant Staphylococcus aureus: report of a clinical failure. Antimicrob. Agents Chemother. 49(3), 1222-1224 (2005).

11 Ghanbari F, Ghajavand H, Havaei R et al. Distribution of erm genes among Staphylococcus aureus isolates with inducible resistance to clindamycin in Isfahan, Iran. Adv. Biomed. Res. 5(1), 62 (2016).

12 Saffar H, Rajabiani A, Abdollahi A, Habibi S, Baseri Z. Frequency of inducible clindamycin resistance among gram-positive cocci in a tertiary hospital, Tehran, Iran. Iran. J. Microbiol. 8(4), 243-248 (2016).

-• Provides mechanism of resistance caused by erm genes and D-zone effect.

13 Khashei R, Malekzadegan Y, Sedigh Ebrahim-Saraie H, Razavi Z. Phenotypic and genotypic characterization of macrolide, lincosamide and streptogramin B resistance among clinical isolates of staphylococci in southwest of Iran. BMC Res. Notes 11(1), 1-6 (2018).

14 Drinkovic D. Clindamycin treatment of Staphylococcus aureus expressing inducible clindamycin resistance. J. Antimicrob. Chemother. 48(2), 315-316 (2001).

15 Fasihi Y, Saffari F, Kandehkar Ghahraman MR, Kalantar-Neyestanaki D. Molecular detection of macrolide and lincosamide-resistance genes in clinical methicillin-resistant Staphylococcus aureus isolates from Kerman, Iran. Arch. Pediatr. Infect. Dis. 5(1), e37761 (2017).

16 Moosavian M, Shoja S, Rostami S, Torabipour M, Farshadzadeh Z. Inducible clindamycin resistance in clinical isolates of Staphylococcus aureus due to erm genes, Iran. Iran. J. Microbiol. 6(6), 421-427 (2014).

17 Gade ND, Qazi MS. Inducible clindamycin resistance among Staphylococcus aureus isolates. Indian J. Basic Appl. Med. Res. 2(8), 961-967 (2013).

18 Navidinia M. Detection of inducible clindamycin resistance (MLSBi) among methicillin- resistant Staphylococcus aureus (MRSA) isolated from health care providers. J. Paramed. Sci. 6(1), 91-96 (2015).

19 Govindan S, Mohammed CA, Bairy I. Inducible clindamycin resistance among the Staphylococcus aureus colonizing the anterior nares of school children of Udupi Taluk. Nepal J. Epidemiol. 4(1), 337-340 (2014).

20 Baiu SH, Al-Abdli NE. Inducible clindamycin resistance in methicillin resistant Staphylococcus aureus. Am. J. Infect. Dis. Microbiol. 4(1), 25-27 (2016).

21 Adhikari RP, Shrestha S, Barakoti A, Amatya R. Inducible clindamycin and methicillin resistant Staphylococcus aureus in a tertiary care hospital, Kathmandu, Nepal. BMC Infect. Dis. 17, 483 (2017). 
- Provided data on inducible clidamycin-resistance Staphylococcus aureus in clinical samples from Nepal.

22 Goudarzi M, Navidinia M, Beiranvand E, Goudarzi H. Phenotypic and molecular characterization of methicillin-resistant staphylococcus aureus clones carrying the panton-valentine leukocidin genes disseminating in iranian hospitals. Microb. Drug Resist. 24(10), 1543-1551 (2018).

23 Cheesbrough M. District Laboratory Practice in Tropical Countries (Part 2) (2nd Edition). Cambridge University Press (CUP). Cambridge, England

24 CLSI. Performance Standards for Antimicrobial Susceptibility Testing (30th Edition). Clinical Laboratory Standard Institute, PA, USA

25 Gurung RR, Maharjan P, Chhetri GG. Antibiotic resistance pattern of Staphylococcus aureus with reference to MRSA isolates from pediatric patients. Futur. Sci. OA. 6(4), 1-9 (2020).

26 Farzana K, Rashid Z, Akhtar N, Sattar A, Khan JA, Nasir B. Nasal carriage of staphylococci in health care workers: antimicrobial susceptibility profile. Pak. J. Pharm. Sci. 21(3), 290-294 (2008).

-. Explains a simple D-test that can be done in laboratory to idenfity inducible clindamycin resistance.

27 Merino-Díaz L, De La Casa AC, Torres-Sánchez MJ, Aznar-Martín J. Detección de resistencia inducible a clindamicina en aislados cutáneos de Staphylococcus spp. por métodos fenotípicos y genotípicos. Enferm. Infecc. Microbiol. Clin. 25(2), 77-81 (2007).

28 Aydeniz Ozansoy F, Cevahir N, Kaleli I. Investigation of macrolide, lincosamide and streptogramin B resistance in Staphylococcus aureus strains isolated from clinical samples by phenotypical and genotypical methods. Mikrobiyol. Bul. 49(1), 1-14 (2015).

29 Abdalla AE, Kabashi AB, Elobaid ME et al. Methicillin and inducible clindamycin-resistant Staphylococcus aureus isolated from postoperative wound samples. J. Pure Appl. Microbiol. 13(3), 1605-1609 (2019).

30 Junaid K, Mustafa AUL, Arshad S, Farraj DAAL, Younas S, Ejaz H. Burn wound infections: a serious threat of multidrug-resistant Staphylococcus aureus. Pak. J. Med. Health Sci. 13(3), 804-807 (2019).

31 De Lima V, Coutinho S, Paiva RM et al. Distribution of erm genes and low prevalence of inducible resistance to clindamycin among staphylococci isolates. Braz. J. Infect. Dis. 14(6), 564-568 (2010).

32 Lina G, Quaglia A, Reverdy ME, Leclercq R, Vandenesch F, Etienne J. Distribution of genes encoding resistance to macrolides, lincosamides, and streptogramins among staphylococci. Antimicrob. Agents Chemother. 43(5), 1062-1066 (1999).

33 Fiebelkorn KR, Crawford SA, McElmeel ML, Jorgensen JH. Practical disk diffusion method for detection of inducible clindamycin resistance in Staphylococcus aureus and coagulase-negative staphylococci. J. Clin. Microbiol. 41(10), 4740-4744 (2003).

34 Chelae S, Laohaprertthisarn V, Phengmak M, Kongmuang U, Kalnauwakul S. Detection of inducible clindamycin resistance in staphylococci by disk diffusion induction test. J. Med. Assoc. Thai. 92(7), 947-951 (2009).

35 Seifi N, Kahani N, Askari E, Mahdipour S, Nasab Naderi M. Inducible clindamycin resistance in Staphylococcus aureus isolates recovered from Mashhad, Iran. Iran. J. Microbiol. 4(2), 82-86 (2012).

36 Timsina R, Timalsina B, Singh A. Screening of erm gene of inducible clindamycin resistant Staphylococcus aureus. J. Inst. Sci. Technol. 24(2), 39-43 (2019). 